\title{
Research on the Inspection and Optimization of Anti-corruption Criminal Rule of Law in Contemporary China
}

\author{
Mengyuan $\operatorname{Sun}^{12, a}$ \\ ${ }^{1}$ College for Criminal Law Science, Beijing Normal University, Beijing, China, 100875 \\ ${ }^{2}$ Law School, Beijing Normal University, Beijing, China, 100875 \\ aa900188@sina.com,
}

\begin{abstract}
Keywords: Anti-corruption, Criminal Rule of Law, Criminal law, Conviction and Sentencing, Rule of Law Thinking
\end{abstract}

\begin{abstract}
Anti-corruption is a common problem and the rule of law issues faced by countries in the world, it is related to the rise and fall of nation and ethnic honor. China's party and government have always attached great importance to anti-corruption work, emphasizing using the rule of law to promote anti-corruption work, insist on building the anti-corruption rule of law system with Chinese characteristics and in line with China's national conditions. However, there still exist a series of problems, such as the imperfect system of criminal law, the concept of criminal rule lagging behind, weak foundation of international cooperation in criminal law and so on, which need to be further adjusted and perfected in the field of anti-corruption criminal rule. Therefore, in order to adapt to the need of anti-corruption criminal rule under the new situation, we should establish a comprehensive anti-corruption criminal rule system, actively update the anti-corruption criminal rule of law, and strengthen anti-corruption international cooperation in criminal law.
\end{abstract}

\section{Introduction}

China is in the critical period of the social transformation and the transformation of the system, and the situation of anti-corruption is extremely serious. The anti-corruption problem has also become the focus of the theorists and practitioners in the world. Criminal law, as the ultimate weapon of anti - corruption struggle, has special rigor and deterrence. It should be used prudently and stably to realize the high integration of political effect, legal effect and social effect. Under the new anti corruption law, the criminal rule of law must be adjusted and perfected in time according to the new situation of anti - corruption and the new background of international anti - corruption, so as to provide a solid criminal rule of law. At the same time, the criminal rule of anti-corruption is the important content of the socialist rule of law with Chinese characteristics, related to the process of China's dream, the basic rights of citizens and the perfection of the rule of law system. Therefore, the study of anti-corruption criminal rule of law not only has important theoretical significance, but also has outstanding practical value.

\section{The Current Anti-Corruption Situation in China}

Corruption is a social cancer, is the impact of economic and social development, national long-term stability of the deadly risk. China's score was 37 points, 1 point higher than 2014, ranking from the first 100 up to No. 83, "Transparency International" released the "Global Clean Impression Index List (CPI)", the famous international NGO. From the data we can see that China is in the ranks of "more serious corruption" countries, corruption is in a high frequency, the frequency of anti-corruption situation is extremely grim. From the severity point of view, in recent years, the phenomenon of corruption tends to be serious, regional corruption, systemic corruption, family corruption, collapse of corruption and other ways; from the complexity of speaking, regional corruption and inter-regional corruption, And the corruption of the coexistence of power, outside the system and the system linked to the power of money transactions, the right to color transactions, the right to trade with the interests of the complex, deep-rooted. 
Since the founding of the PRC in 1949, the Party and the government have always taken the fight against corruption as the most important task. Comrade Mao Zedong put forward in the war years to oppose "corruption" and to Comrade Deng Xiaoping's "one hand grasp the reform and opening up, Comrade Jiang Zemin's "tackling both the symptoms and the root and the comprehensive treatment" and then Comrade Hu Jintao's "resolute and three-plus", and then Comrade Xi Jinping's "cage into the system of power." Since the 18th CPC National Congress, the party and the government have attached great importance to the struggle against corruption, carried out the activities of party conduct and incorruptible government building and mass line practice, strived to achieve the goal of "not rotting, not rotting, not wanting to rot," reducing corruption stock; , Reconstruction of China's political ecology. Of course, we must be soberly aware of the anti-corruption struggle is not an overnight thing, China's anti-corruption struggle situation is still very grim, punish and prevent corruption in China will be a long process and arduous task.

As a key measure in the system of punishing and preventing corruption, the rule of criminal law plays an important role in the struggle against corruption, and it is of special severity and deterrence. At present, China's criminal law has basically included various types of corrupt crimes, procedural justice and penalty civilization, perfect the system to become the main content of the anti-corruption criminal rule of law, anti-corruption criminal rule of law is increasingly modernized, standardized and scientific. Since the founding of 1949, China's anti-corruption criminal rule of law presents the following three characteristics: First, the continuous improvement of criminal policy against corruption. From the previous "strike hard", "special rectification" and other sports-oriented governance to the "root cause, comprehensive treatment, both punishment and prevention, pay attention to prevention" change, and pay attention to anti-corruption criminal policy of the legal system, through the legal system, anti- clear. Second, anti-corruption criminal legislation is increasingly sound. At present, the criminal law system of corruption is more complete, and the punishment of corruption is also more scientific. Third, anti-corruption criminal justice is more scientific. Anti-corruption criminal justice focuses on the unity of application, insisting on the combination of principle and specificity. Anti-corruption criminal justice attaches importance to its long-term and stability, emphasizing the organic integration of current and long-term, part and whole.

Under the new situation of world situation, national conditions and profound changes in the party's situation, the criminal rule of law against corruption must be adjusted and improved in time to solve the new tasks, demands and problems under the new situation, and to build a Chinese-style anti- Corruption, the rule of law system. There are many problems in the process of modern China's anti-corruption criminal rule in realizing modernization, standardization and scientificization, which restricts the development of the system of criminal rule of law against corruption and the development of the rule of law in socialism with Chinese characteristics. Therefore, it is necessary to deeply analyze the main problems of the criminal rule of anti-corruption in contemporary China. Combining with the current situation of anti-corruption and anti-corruption criminal rule of law, the author puts forward corresponding ideas and suggestions.

\section{The Main Problems of the Criminal Rule of Law against Corruption in Contemporary China}

The Anti-Corruption Criminal Rule of Law Is Not Tight. Although China has basically formed a strict, systematic anti-corruption criminal rule of law, but with the current actual needs of the fight against corruption, there are still many shortcomings. Specifically, the following three aspects: First, the behavior object is not scientific. China's Criminal Law restricts the content of "bribery" to "property" in the bribery crime. Although the Supreme Judicial Interpretation and Supreme People's Court's judicial interpretation in 2007 expanded the scope of "bribery" to "property interest", "non-property Interest "is still not included in the scope of" bribery "; the same time, China's" Criminal Law "provides only three kinds of misappropriation of crime, behavior objects are public funds, unit funds and specific funds and materials, and for non-specific public objects of behavior has not yet incorporated into criminal law Range. Second, the behavior is limited to unscientific. China's Criminal Law stipulates that "the delivery of property" or "the actual giving" only 
constitutes the completed form of bribery crime, and "promised to" or "proposed to give", only as unfinished form disposition. Therefore, China's current "Criminal Law" is clearly inconsistent with the international mainstream view. Third, the limitation of behavior purpose is not scientific. China's "Criminal Law" stipulates that the constituent elements of bribery require actors to subjectively "for the purpose of seeking undue benefits", which obviously will seek the "legitimate interests" excluded from the subjective constitution of bribery, limited too narrow, not Conducive to fighting corruption.

The Concept of Anti-Corruption Criminal Rule of Law Lag Behind. Anti-corruption is a long-term systematic project, and it needs to establish a long-term mechanism of anti-corruption, which cannot rely solely on criminal means to combat the "anti-corruption", "an all-round, multi-level and wide-ranging" Corruption crime. At present, there are many places in our country rely heavily on criminal law means to combat corruption in the phenomenon, that the strict use of penalties can effectively combat and deter corruption, deviate from the "rule of law against corruption" track. At the same time, our anti-corruption in the use of penalties there are some bad preferences, for major cases, the case is strictly dealt with severely, and for some minor circumstances, the smaller social impact of the case of job-related crimes is a light tendency, The perpetrators of corruption do not prosecute, exempt from punishment or sentenced to probation. In the process of advancing the modernization of the criminal rule of anti-corruption, these problems are obviously not conducive to the construction of anti-corruption criminal rule.

The International Cooperation Base of Anti-Corruption Rule of Law Is Weak. Due to the differences in the political, economic and cultural aspects of the world, the anti-corruption legal system formulated by various countries also has many discrepancies. China's anti-corruption strategy has always adopted a heavy punishment against corruption, while the western developed countries for criminal offenses are tight criminal responsibility, less severe punishment. At present, the forms of international criminal judicial cooperation are extradition, criminal judicial assistance and transfer of criminal proceedings, recognition and enforcement of criminal judgments, of which extradition is the main form of international cooperation against corruption. At present, China has less bilateral extradition treaties with Western developed countries, and Western developed countries have little understanding of China's anti-corruption criminal rule, and the channels of international cooperation in combating corruption are not smooth. At the same time, there are differences between the relevant provisions of China's Criminal Law on corruption and the provisions of the Western developed countries and the United Nations Convention against Corruption, which also hinders international cooperation in the criminal rule of anti-corruption.

\section{The Optimization Path of Chinese Anti-Corruption Criminal Rule of Law}

Establish a Comprehensive Anti-Corruption Criminal Rule of Law System. A comprehensive anti - corruption criminal law system can provide solid criminal legal guarantee for anti - corruption struggle, and play a better role of deterrence and punishment. Therefore, China should improve the system of anti-corruption criminal law through criminal legislation, which can proceed from the following three aspects: First, expand the scope of the object of action. China can learn from the western developed countries and the United Nations Convention against Corruption in the relevant provisions of corruption in the "bribery" content from the "property interests" to "non-property interests"; the same time, the embezzlement of public funds, The object of embezzlement of funds shall be expanded from "public funds" and "funds" to "property" and the "personal use" restriction on the misappropriation of public funds or misappropriation of funds for profit or illegal activities shall be abolished. Second, regulate the behavior of qualified. To expand the behavior of corruption, will promise to give the proposed benefits to the conduct of corruption into the scope of the crime. Third, regulates the restrictions behavior purpose. China should abolish the relevant provisions of "seeking benefits for others" and bribery "for illegitimate interests" in the crime of accepting bribes, and reduce the resistance to the determination of corruption in judicial practice, and can effectively expand the scope of criminal acts of corruption and exert criminal deterrence effect.

Actively Update the Concept of Anti-Corruption Criminal Rule of Law. Thought is the 
forerunner of action, leading the way forward. In view of the current lag of the concept of criminal rule of law against corruption in a number of issues, we should actively update the concept of anti corruption criminal rule of law. Specifically, we can proceed from the following two aspects: First, establish anti-corruption concept of the rule of law against criminal rule of law. Adhere to the use of rule of law thinking and the rule of law to carry out anti-corruption work, lay not rot, not rot, do not want to rot the cornerstone of the rule of law and institutional basis, so that anti-corruption standardization, institutionalization and scientific anti-corruption become the new normal. Second, establish anti-corruption criminal rule of modesty concept. It is not advisable to control corruption through rigorous punishment, and it is necessary to prevent and punish corruption through four aspects: systematic governance, legal governance, comprehensive governance, and source governance. The criminal law should be defined as the crime of punishing corruption the ultimate means. Thirdly, establish the concept of temper justice with mercy in the criminal rule of anti-corruption. In the prevention and punishment of corruption, we should pay attention to the use of criminal policy of temper justice with mercy, and strive to achieve political, legal and social effects of the organic unity.

Strengthen the International Cooperation in Anti-Corruption Criminal Rule of Law. Nowadays, anti-corruption is no longer a country or a region, but a common problem faced by all countries in the world. Therefore, we should strengthen the international cooperation in the criminal rule of anti-corruption and build a network of global anti-corruption criminal rule. First of all, we should establish the concept of advanced anti-corruption criminal rule of law, learn from international successful experience and improve the relevant legislation and technology. Secondly, do a good job anti-corruption international and domestic criminal law, the rule of law in developed countries and the United States, "United Nations Convention against Corruption" convergence, to reduce international institutional barriers to cooperation. Finally, perfect the anti-corruption related legal system, strengthen the human rights safeguard function in the criminal rule of anti-corruption, realize the justice of justice, civil justice, and promote the internationalization of China's anti-corruption criminal rule.

\section{Conclusion}

Contemporary China has entered a critical period of the anti-corruption criminal rule of law. Therefore, we must keep abreast of the actual situation and development needs of China's anti-corruption, deal with the existing anti-corruption criminal related issues with new thinking, new methods and new experience. Take advanced criminal rule of law as the guide, actively and steadily promote China's anti-corruption criminal rule of law reform, and strive to achieve China's anti-corruption criminal rule of law modern, standardized and scientific, and convergence with international anti-corruption criminal rule of law. At the same time, we must realize that the anti-corruption criminal rule as an important content in the modern rule of law, it plays an important role in the construction of the Chinese characteristics socialist rule of law. We must advance with the times, blaze new trails and meet the actual needs of anti-corruption struggle to achieve the rule of law in China to provide a solid and powerful criminal rule of law protection.

\section{References}

[1] Chu Huaizhi, Yan Yu. Study on the Criminal Law of Corruption in Contemporary China - From the Perspective of United Nations Convention against Corruption [J]. Journal of South-Central University for Nationalities (Humanities and Social Sciences) , 2013 (3): 106-112.

[2] Cao Hua. On the perfection and perfection of China's anti-corruption criminal legal system From the perspective of "United Nations Convention against Corruption" [J]. Academic Exploration, 2013 (1): 104-108.

[3] Gao Mingxuan, Chen Ran. Research on the criminal rule of law in the social management innovation [J]. Chinese Prosecutor, 2012 (11): 54-66. 
[4] Hao Rihong. From the "four aspects" to promote anti-corruption legislation [N]. Chinese Social Science Journal, 2015-03-13 (A06).

[5] Wei Dong. An Interpretation of Current Anti-corruption Policy in China [J]. Regular Governance Research, 2013 (9): 3-7.

[6] Yuan Jian-wei. The Logic Development of Criminal Rule of Law [J]. Chinese Journal of Criminal Law, 2014 (2): 18-24.

[7] Zhao Bingzhi. Chinese anti-corruption criminal rule of law a number of major practical problems [J]. Law Review, 2014 (3): 1-17.

[8] Zhao Bingzhi. Make efforts to create a new situation in the development of China's criminal rule of law [J]. Chinese Universities Social Science, 2014 (6): 14-16. 